\title{
PARTIAL PURIFICATION AND CHARACTERIZATION OF RIBONUCLEASES FROM ROOTS, STEM AND LEAVES OF COWPEA ${ }^{1}$
}

\author{
OCTÁVIO LUIZ FRANCO ${ }^{2}$, LORRANCE ABREU GONDIM ${ }^{3}$, KÁTIA REGINA \\ BEZERRA ${ }^{3}$, MARIA ELANE DE CARVALHO GUERRA ${ }^{2}$, CARMEM ROGÉLIA \\ FARIAS MACHADO LIMA ${ }^{2}$, JOAQUIM ENÉAS-FILHO ${ }^{4}$, JOSÉ TARQUÍNIO \\ PRISCO $^{5}$, ENÉAS GOMES-FILHO ${ }^{6}$
}

\author{
Laboratório de Fisiologia Vegetal, Departamento de Bioquímica e Biologia Molecular, Universidade \\ Federal do Ceará, P.O. Box 6039, 60.455-900, Fortaleza, Ceará, Brazil
}

\begin{abstract}
Partial purification and characterization of ribonucleases (RNase; EC 3.1.27.1) present in roots, stem and leaves of 5 day-old Pitiúba cowpea [Vigna unguiculata (L.) Walp.] seedlings are described. Crude extracts from the different tissues were precipitated with ammonium sulfate followed by ionic exchange chromatography (CM-Cellulose) resulting in purification factors of 48 -fold for roots, 21 for stem and 42 for leaves. No deoxyribonuclease activity was practically observed. The molecular masses of the RNases did not significantly differ, averaging $16.3 \mathrm{kDa}$. Leaf RNase was stable up to $50^{\circ} \mathrm{C}$ while the others were inactivated at this temperature. The maximal inactivation for both stem and roots RNases was reached at $70^{\circ} \mathrm{C}$ while for leaf it occurred at $80^{\circ} \mathrm{C}$. The addition of $\mathrm{KCl}$ to the assay medium caused a shift of optimal $\mathrm{pH}$ from 6.0 toward the range of 5.2-5.6 for the enzymes extracted from the different tissues. RNase activities were strongly inhibited by $\mathrm{Hg}^{2+}, \mathrm{Zn}^{2+}$ and $\mathrm{Cu}^{2+}$, partially inhibited by $\mathrm{Co}^{2+}$ and $\mathrm{Fe}^{2+}$ and were not affected by EDTA, $\mathrm{Ca}^{2+}$ or $\mathrm{Mg}^{2+}$. In contrast to the leaf RNase, roots and stem enzymes were inactivated by urea and 2-mercaptoethanol (2-ME). Although there is a great similarity among the enzymes studied, leaf RNase appears to be more stable to heat and to chemical denaturation than root and stem RNases. The results also suggest that the enzymes extracted from different tissues of Pitiúba cowpea seedlings are ribonucleases and not nucleases.
\end{abstract}

ADDITIONAL INDEX TERMS - Enzyme effectors, molecular mass, nuclease, optimum pH, seedlings, thermostability, Vigna unguiculata.

\section{PURIFICAÇÃO PARCIAL E CARACTERIZAÇÃO DAS RIBONUCLEASES DE RAÍZES, CAULE E FOLHAS DE FEIJÃO-DE-CORDA}

RESUMO - Este trabalho descreve a purificação parcial e caracterização das ribonucleases (RNase; EC 3.1.27.1) presentes em raízes, caule e folhas de plântulas de feijão-de-corda Pitiuba [Vigna unguiculata (L.) Walp.]. Precipitação dos extratos brutos dos diferentes tecidos com sulfato de amônio, seguida de cromatografia de troca iônica (CM-Celulose), resultaram em purificação de cerca de 48 vezes para a

1. Received: 22/2/2001 - Accepted: 15/9/2001

2. Biólogo, Bolsista CNPq

3. Eng. de Alimentos, Bolsista CNPq

4. Biólogo, M.S., Dr., Prof. Adjunto IV, Pesquisador CNPq

5. Eng. Agron., M.S., Ph.D., Prof. Emérito, Pesquisador CNPq

6. Eng. Quim., M.S., Dr., Prof. Adjunto IV, Pesquisador CNPq - Corresponding author: Fax: 0XX-85-288-9829; e-mail: egomesf@ufc.br 
enzima de raízes, 21 para a de caule e 42 para a de folha. A atividade desoxirribonucleásica nas frações semi-purificadas foi praticamente nula. As massas moleculares das RNases não diferiram significativamente, sendo a média de suas massas $16,3 \mathrm{kDa}$. A RNase de folha mostrou-se estável até $50^{\circ} \mathrm{C}$ enquanto que as outras foram inativadas nesta temperatura. A inativação máxima das RNases de raízes e de caule ocorreu a $70^{\circ} \mathrm{C}$, mas a da RNase foliar ocorreu a $80^{\circ} \mathrm{C}$. A adição de $\mathrm{KCl}$ ao meio de ensaio causou uma mudança no $\mathrm{pH}$ ótimo de 6,0 para a faixa de 5,2-5,6 para as enzimas extraídas dos diferentes tecidos. As atividades RNásicas foram fortemente inibidas por $\mathrm{Hg}^{2+}, \mathrm{Zn}^{2+}$ e $\mathrm{Cu}^{2+}$, inibidas parcialmente por $\mathrm{Co}^{2+}$ e $\mathrm{Fe}^{2+}$ e não foram afetadas por EDTA, $\mathrm{Ca}^{2+}$ ou $\mathrm{Mg}^{2+}$. Diferentemente do observado para a RNase foliar, as enzimas de raízes e de caule foram inativadas por uréia e 2mercaptoetanol (2-ME). Embora exista grande semelhança entre as enzimas estudadas, a RNase foliar parece ser mais estável ao calor e à desnaturação química do que as RNases de raiz e de caule. Os resultados sugerem que as enzimas extraídas dos diferentes tecidos de plântulas de feijão-de-corda Pitiúba são ribonucleases e não nucleases.

TERMOS ADICIONAIS PARA INDEXAÇÃO: Efetores da enzima, massa molecular, nuclease, pH ótimo, plântula, termoestabilidade, Vigna unguiculata.

\section{INTRODUCTION}

Ribonucleases (RNase; EC 3.1.27.1) have a key role on plant development due to their ability to modify RNA levels, and thereby influence protein synthesis (Tvorus, 1976). Hydrolysis and mobilization of RNA in seed tissues are important steps during germination and seedling establishment (Bewley \& Black, 1994). Ribonucleases have previously been isolated from several organisms such as, fungi (Wang \& $\mathrm{Ng}$, 1999), higher plants (Gomes-Filho \& Sodek, 1988; Nakagawa et al., 1999; Tanaka et al., 2000) and mammals (Pileur et al., 2000). There are four types of enzymes that hydrolyze RNA in plants: RNase I, RNase II, nuclease I and exonuclease I (Wilson, 1975, 1982). While RNases uses only RNA as substrate and are insensitive to EDTA, nucleases hydrolyze both RNA and DNA and are highly affected by EDTA (Wilson, 1975, 1982; Green, 1994).

Cellular RNA level is a function of the balance between synthesis and degradation (Farkas, 1982) and plants are known to alter the levels of RNase activities in response to endogenous or exogenous stimuli (Farkas, 1982; Wilson, 1982; Gomes-Filho \& Sodek, 1988; Dodds et al., 1996). However, the mechanisms involved in these processes are poorly understood (GomesFilho et al., 1999), and in order to understand these mechanisms it is fundamental to isolate and characterize the different types of RNases.
Ribonuclease characteristics have been studied in the different Vigna unguiculata tissues during germination and seedling development (GomesFilho \& Enéas-Filho, 1991), but only cotyledon RNase has been purified and characterized (Gomes-Filho et al., 1999). Furthermore, the name RNase has been used without knowing whether or not the activity measured is a mixture of nucleases and RNases because only RNA is generally tested as substrate.

Therefore, the objectives of the present paper were to determine possible differences among the RNases from different organs of cowpea seedlings and to clarify if they are true RNases or nucleases. RNases from roots, stem and leaves were partially purified and some of their kinetic and physical chemical properties studied. The enzymatic characteristics studied were: activity against DNA, molecular masses, heat stability, $\mathrm{pH}$ curves, and action of some effectors on the enzyme activities.

\section{MATERIAL AND METHODS}

\section{Plant material}

Pitiúba cowpea [Vigna unguiculata (L.) Walp.] seeds were obtained from plants grown under irrigation at the Centro de Ciências Agrárias, Universidade Federal do Ceará, Fortaleza, Ceará, Brazil. Seeds were kept at $10^{\circ} \mathrm{C}$ in glass flasks 
containing silica gel. Seeds, previously surfacesterilized with sodium hypochloride, were allowed to germinate on filter paper (Prisco \& Vieira, 1976) at $25 \pm 2^{\circ} \mathrm{C}$ in darkness.

\section{Ribonuclease extraction and purification}

Roots, stems and leaves from Pitiúba cowpea seedlings at 5 days after seeding were used to obtain RNases crude extracts. The different tissues were ground in $0.1 \mathrm{M}$ potassium phosphate buffer, pH 5.7 (1:3; w/v), at $4^{\circ} \mathrm{C}$ (Gomes-Filho \& Enéas-Filho, 1991). The extracts were left without stirring for $30 \mathrm{~min}$, passed through a nylon filter and centrifuged at $7000 \mathrm{xg}$ for $20 \mathrm{~min}$ at $4^{\circ} \mathrm{C}$. The supernatant (crude extract) was precipitated with ammonium sulfate $(40-80 \%$ saturation) and the pellet obtained after centrifugation was resuspended in $0.1 \mathrm{M}$ sodium acetate buffer, $\mathrm{pH}$ 4.5, dialyzed against the same buffer overnight, and finally dialysed against cold distilled water for $24 \mathrm{~h}$. This fraction $\left(\mathrm{F}_{40-80}\right)$ was centrifuged and the supernatant was lyophilized and stored at $4^{\circ} \mathrm{C}$.

The lyophilized $\mathrm{F}_{40-80}$ was resuspended in cold $0.1 \mathrm{M}$ sodium acetate buffer, $\mathrm{pH} 4.5$, and applied to a carboxymethyl-cellulose (CMCellulose) column (18 x $175 \mathrm{~mm})$ equilibrated with the same buffer at $10^{\circ} \mathrm{C}$. The flow rate was adjusted to $32 \mathrm{~mL} \cdot \mathrm{h}^{-1}$, and after washing the column with the initial buffer, proteins were eluted with a $0-1 \mathrm{M} \mathrm{NaCl}$ gradient $(100 \mathrm{~mL})$ and $3.5 \mathrm{~mL}$ fractions were collected. The fractions containing ribonuclease activity ( $\mathrm{F}_{\mathrm{CM}}$ fraction) were pooled, dialyzed against cold distilled water and lyophilized for enzyme characterization.

Protein was determined according to Bradford (1976), using bovine serum albumin (Sigma Chemical Co.) as standard or expressed as absorbance at $280 \mathrm{~nm} \quad\left(\mathrm{~A}_{280}\right)$, for the chromatographic fractions.

\section{Ribonuclease and deoxyribonuclease activity}

RNase activity was assayed according to Tuve \& Anfinsen (1960) with minor modifications (Gomes-Filho \& Enéas-Filho, 1991), using yeast RNA type IV (Sigma Chemical Co.) as substrate.
Deoxyribonuclease activity was determined according to Wilson (1968), using linear DNA from Salmon sperm (Sigma Chemical Co.) as substrate. In both assays, the substrates were dissolved in $0.1 \mathrm{M}$ sodium acetate buffer, $\mathrm{pH} 5.8$ and the assay temperature was $40^{\circ} \mathrm{C}$. The reaction was terminated by addition of $0.75 \%$ uranyl acetate in $\mathrm{HClO}_{4}$ at $25 \%$, and acid-soluble nucleotide production was determined spectrophotometrically at $260 \mathrm{~nm}$. Enzyme activity was expressed as difference in absorbance $\left(\Delta A_{260}\right)$.

\section{Molecular mass}

Molecular masses were obtained with a Sephadex G-100 column $(25 \times 320$ $\mathrm{mm}$ ) using $0.1 \mathrm{M}$ sodium acetate buffer, $\mathrm{pH} 5.8$. The column flux was adjusted to $32 \mathrm{~mL} \cdot \mathrm{h}^{-1}$ and fractions of $4.3 \mathrm{~mL}$ were collected. Protein and RNase activity were determined as described above. The molecular mass was calculated according to Determan (1969). The chromatographies were carried out in triplicate.

\section{Ribonuclease properties}

Thermostability was obtained with 0.2 $\mathrm{mL} \mathrm{F}_{\mathrm{CM}}$ fractions in $0.1 \mathrm{M}$ sodium acetate buffer, $\mathrm{pH} 5.8$, preincubating at temperatures ranging from 30 to $100^{\circ} \mathrm{C}$, for $10 \mathrm{~min}$, followed by cooling on ice bath and determining the residual enzyme activity. Three independent experiments were carried out, each one in triplicate.

Optimum $\mathrm{pH}$ of $\mathrm{F}_{\mathrm{CM}}$ was assayed in sodium acetate buffer ( $\mathrm{I}=0.05, \mathrm{pH} 4.0$ to 6.0$)$ and in sodium phosphate buffer ( $\mathrm{I}=0.05, \mathrm{pH} 6.4$ to 7.6). Enzyme activity as a function of $\mathrm{pH}$ was determined both in the presence and absence of $0.16 \mathrm{M} \mathrm{KCl}$. Three independent experiments were carried out, each one in triplicate.

The effect of divalent cations on the enzyme activity was investigated by adding chloride salts to the reaction mixture at $3.0 \mathrm{mM}$ final concentration. The effects of urea and 2mercaptoethanol (2-ME) were studied by preincubating $\mathrm{F}_{\mathrm{CM}}$ fraction with $6.0 \mathrm{M}$ urea and 140 
$\mathrm{mM} 2-\mathrm{ME}$ for $1 \mathrm{~h}$ at $25^{\circ} \mathrm{C}$, and the enzyme activity assayed at a final concentration of $1.0 \mathrm{M}$ urea and $140 \mathrm{mM}$ of 2-ME. Three independent experiments were carried out, each one in duplicate.

\section{RESULTS AND DISCUSSION}

\section{Purification of ribonucleases}

Ribonucleases from roots, stem and leaves of Pitiúba cowpea seedlings were purified 48-, 21- and 42-fold, respectively (Table 1). The CM-Cellulose chromatography (Figure 1A) has shown that the RNase from leaves was retained and eluted in a single peak with a $\mathrm{NaCl}$ gradient. Similar results were observed for roots and stems (data not shown). No deoxyribonuclease activities were practically detected in $\mathrm{F}_{\mathrm{CM}}$ fraction from roots, stems and leaves (data not shown). Therefore, these data suggest that the enzymes studied are RNases and not nucleases, as defined by Wilson $(1975,1982)$. Similar results were obtained with cotyledonary RNase from the same cultivar (Gomes-Filho \& Sodek, 1988).

TABLE 1. Purification of RNase from Pitiúba cowpea roots, stems and leaves. Five day-old seedlings were used to perform the enzyme purification. For explanation of steps $\mathrm{F}_{40-80}$ and $\mathrm{F}_{\mathrm{CM}}$ see Material and Methods; values in parentheses represent purification (fold).

\begin{tabular}{lccc}
\hline \multirow{2}{*}{ Step } & \multicolumn{3}{c}{ Specific activity $\left(\Delta \mathrm{A}_{260} \cdot \mathrm{mg}^{-1}(\right.$ prot $\left.) \cdot \mathrm{h}^{-1}\right)$} \\
\cline { 2 - 4 } & Roots & Stems & Leaves \\
\hline $\begin{array}{l}\text { Crude } \\
\text { extract }\end{array}$ & $39(1)$ & $19(1)$ & $18(1)$ \\
$\mathrm{F}_{40-80}$ & $192(5)$ & $186(10)$ & $30(2)$ \\
$\mathrm{F}_{\mathrm{CM}}$ & $1889(48)$ & $397(21)$ & $764(42)$ \\
\hline
\end{tabular}

\section{Ribonuclease properties}

RNase from leaves, roots and stems, eluted from Sephadex G-100 column, have shown a single peak of activity with an average molecular mass of about $16.3 \mathrm{kDa}$
(Figure 1B). Cotyledonary RNase extracted from the same cultivar has shown a molecular mass of $16.0 \mathrm{kDa}$, determined by SDS-PAGE (GomesFilho et al., 1999) and RNases with molecular mass of $17.0 \mathrm{kDa}$ were found in maize (Fennoy et al., 1997) and white lupin (Bantignies et al., 2000) roots. RNases with smaller molecular masses (8-14 $\mathrm{kDa}$ ) have also been found in wheat seedlings (Zhao et al., 2000).
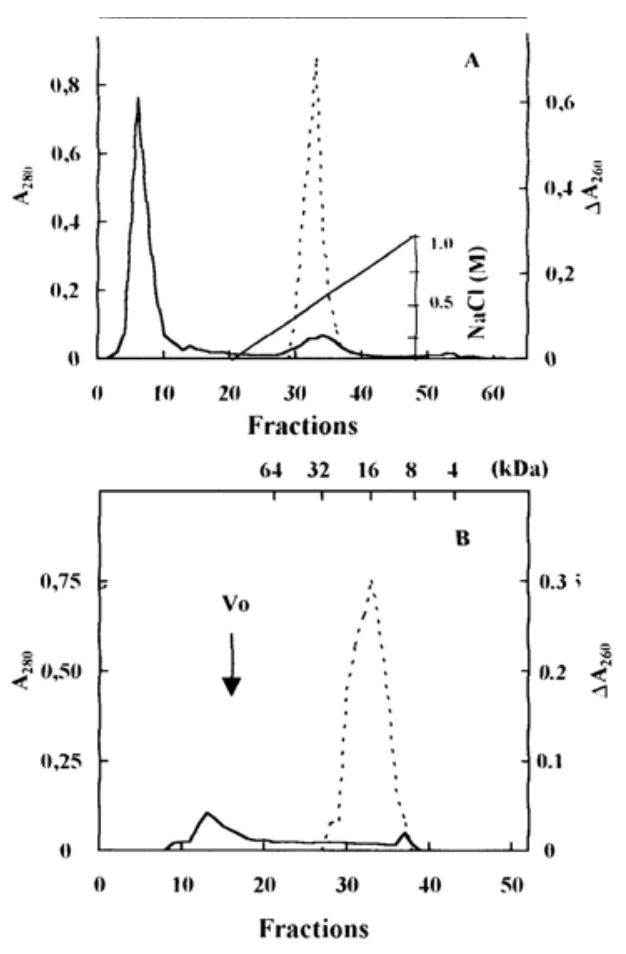

FIGURE 1 - CM-Cellulose chromatography of the ammonium sulfate precipitated fraction $\left(\mathrm{F}_{40-80}\right)$ from leaf extract obtained from 5 day-old Pitiúba cowpea seedlings (A). Chromatography of RNase richest fraction $\left(F_{C M}\right)$ on Sephadex G-100 (B). The estimated molecular masses and exclusion volume (Vo) are indicated (B). Protein $\left(-, \mathrm{A}_{280}\right)$ and RNase activity (----,$\left.\Delta \mathrm{A}_{260}\right)$. For details see Material and Methods.

Thermostability measurements (Figure 2) showed that the ribonuclease from leaves was stable up to $50^{\circ} \mathrm{C}$, while stem and roots enzymes 
were inactivated at this temperature. The maximal inactivation for both stems and roots RNases was reached at $70^{\circ} \mathrm{C}$, while leaves RNase maximal inactivation occurred at $80^{\circ} \mathrm{C}$, suggesting that the latter enzyme was more thermostable. All RNases have shown a tendency to be more stable at temperatures above their maximal inactivation. Similar results were observed for wheat RNase (Hanson \& Fairley, 1969) and for partially purified cowpea cotyledonary RNase (Gomes-Filho et al., 1994). However, when this cowpea RNase was purified this was not observed (Gomes-Filho et al., 1999), suggesting the presence of more thermostable contaminants.

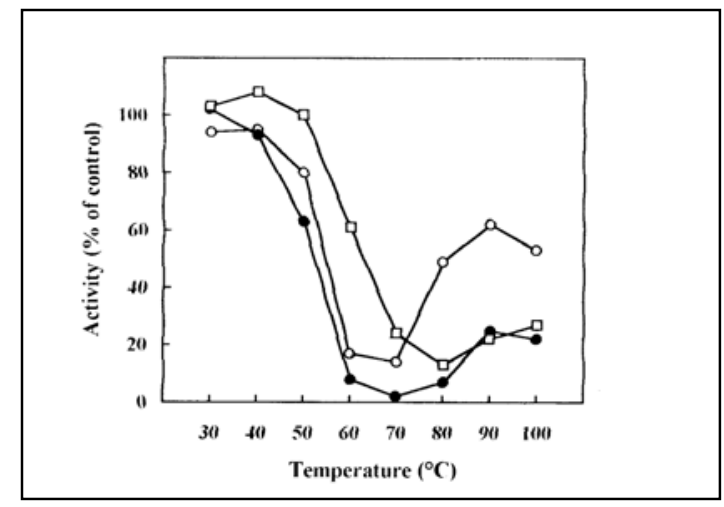

FIGURE 2 - Thermostability study of RNases. Partially purified enzymes from roots $(\Phi)$, stems (M) and leaves $(\Theta)$ of 5 day-old Pitiúba cowpea seedlings were preincubated at the temperatures indicated and the residual activities were determined as described in Material and Methods.

The optima $\mathrm{pH}$ values for RNases extracted from roots (Figure 3A), stem (Figure 3B) and leaves (Figure 3C) were close to 6.0 when $\mathrm{KCl}$ was not present. The addition of $\mathrm{KCl}$ caused a shift of optimal $\mathrm{pH}$ toward the range of 5.2-5.6. The decrease in optima $\mathrm{pH}$ due to the presence of $\mathrm{KCl}$ suggest that they are similar to the RNase I extracted from maize scutellum (Wilson, 1963).

The effects of divalent cations and other effectors on RNases extracted from roots, stem and leaves are shown on Table 2. $\mathrm{Ca}^{2+}$ and $\mathrm{Mg}^{2+}$ caused a slight inhibition (lower than 17\%), while
$\mathrm{Hg}^{2+}, \mathrm{Zn}^{2+}$ and $\mathrm{Cu}^{2+}$ strongly inhibited the RNase activity (greater than $88 \%$ ). This strong inhibition due to heavy metals $\left(\mathrm{Hg}^{2+}, \mathrm{Zn}^{2+}\right.$ and $\left.\mathrm{Cu}^{2+}\right)$ suggest that one or more free sulphydryl groups are present within the active site region of the enzyme (Biswas, 1987, Nelson \& Cox, 2000). $\mathrm{Fe}^{2+}$ inhibited the different RNase activities to a varying
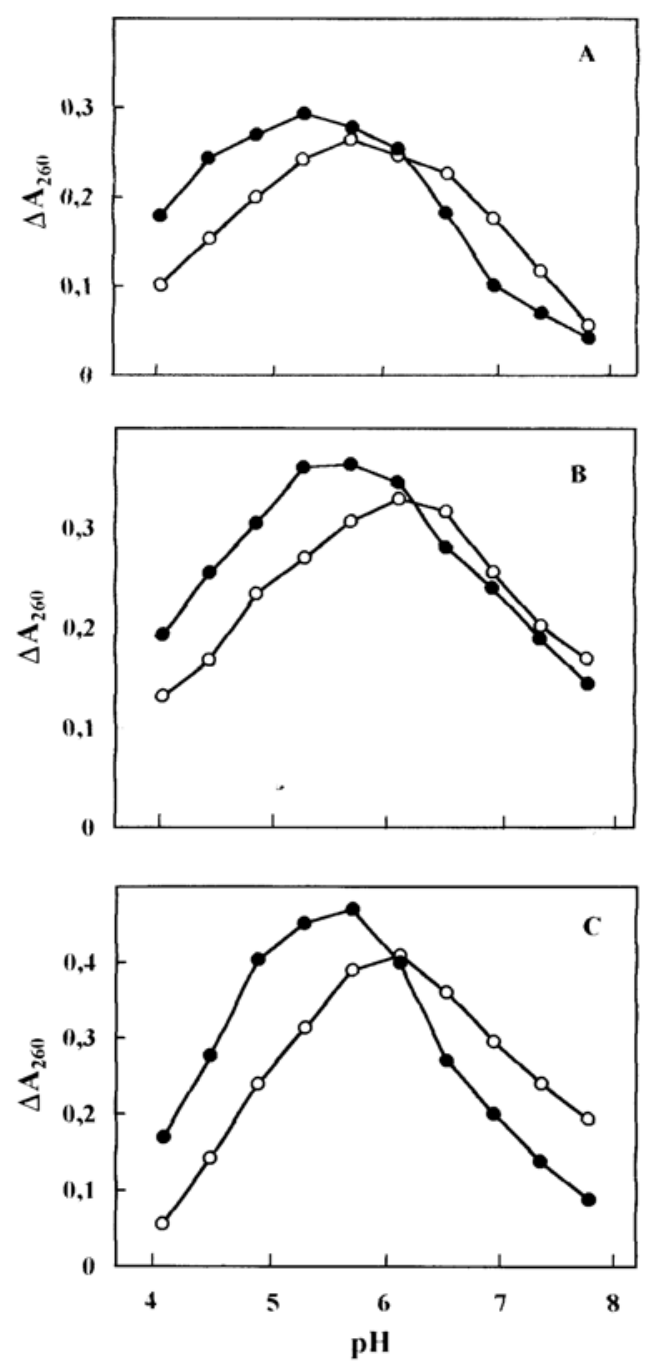

FIGURE 3 - Enzyme activity as a function of $\mathrm{pH}$. Partially purified RNase extracted from roots (A), stems (B) and leaves (C) of 5 day-old Pitiúba cowpea seedlings were incubated at different $\mathrm{pH}$ values, as indicated, in the absence $(\Phi)$ or presence (M) of $0.16 \mathrm{M} \mathrm{KCl}$. 
TABLE 2 - Effect of different chemicals on RNase activity from roots, stems and leaves. Compounds were tested on enzyme purified from 5 day-old Pitiúba cowpea seedlings; $100 \%$ activity (absence of effectors) corresponds to 1889,397 and $764 \Delta \mathrm{A}_{260} \cdot \mathrm{mg}^{-1}$ (prot). $\mathrm{h}^{-1}$ for roots, stems and leaves, respectively. The values are expressed as percentagem \pm standart deviation.

\begin{tabular}{|c|c|c|c|c|}
\hline \multirow{2}{*}{ Effector } & \multirow{2}{*}{$\begin{array}{l}\text { Concentration } \\
\qquad(\mathrm{mM})\end{array}$} & \multicolumn{3}{|c|}{ Activity ( $\%$ of control) } \\
\hline & & Roots & Stems & Leaves \\
\hline Control & - & 100 & 100 & 100 \\
\hline $\mathrm{CaCl}_{2}$ & 3 & $90 \pm 2.1$ & $83 \pm 5.7$ & $90 \pm 4.0$ \\
\hline $\mathrm{MgCl}_{2}$ & 3 & $88 \pm 2.7$ & $92 \pm 4.2$ & $90 \pm 7.0$ \\
\hline $\mathrm{CoCl}_{2}$ & 3 & $63 \pm 1.5$ & $72 \pm 2.8$ & $55 \pm 12.1$ \\
\hline $\mathrm{FeCl}_{2}$ & 3 & $59 \pm 18.0$ & $25 \pm 15.0$ & $36 \pm 4.2$ \\
\hline $\mathrm{HgCl}_{2}$ & 3 & $1 \pm 1.7$ & $12 \pm 2.7$ & $2 \pm 2.9$ \\
\hline $\mathrm{ZnCl}_{2}$ & 3 & $1 \pm 1.2$ & $2 \pm 2.3$ & $2 \pm 2.5$ \\
\hline $\mathrm{CuCl}_{2}$ & 3 & $0 \pm 0$ & $5 \pm 2.8$ & $6 \pm 2.0$ \\
\hline EDTA & 3 & $107 \pm 3.1$ & $88 \pm 2.7$ & $96 \pm 15.3$ \\
\hline 2-ME & 140 & $63 \pm 18.0$ & $41 \pm 13.0$ & $103 \pm 12.9$ \\
\hline Urea & 1000 & $67 \pm 9.1$ & $52 \pm 0.0$ & $113 \pm 6.2$ \\
\hline
\end{tabular}

extent: $41 \%$ in roots, $75 \%$ in stems and $64 \%$ in leaves. The effects of ions on the RNase activity were similar to those observed for the enzymes from rice seeds (Yokoyama et al., 1982) and sunflower roots (El-Shouny \& Alexandrescu, 1986). EDTA caused little change in the RNase activities as also observed for cotyledonary RNases from cowpea (Gomes-Filho et al., 1994). Root and stem RNases were inactivated by urea and 2-ME, while the leaf enzyme was insensitive to 2-ME and slightly stimulated by urea. The changes in root and stem RNases induced by urea and 2-ME are the result of changes in the tertiary structure of the enzyme, i.e., protein denaturation due to urea, and reduction of disulfide bridges due to 2-ME. These results and the higher thermostability found for 
the RNase extracted from leaves suggest that this protein is more resistant to denaturation and less dependent on disulfide bonds for its stability than the RNases extracted from roots, stem and cotyledons.

Our results suggest that the enzymes extracted from different tissues of Pitiúba cowpea seedlings are ribonucleases and not nucleases. Even though there are great similarities among the different RNases studied, the enzyme from leaves seems to be more stable to heat and to chemical denaturation, than roots and stem RNases.

\section{ACKNOWLEDGEMENTS}

We thank Daniel J. Rigden for reviewing the English. This work was supported by Financiadora de Estudos e Projetos (FINEP) and by Conselho Nacional de Desenvolvimento Científico e Tecnológico (CNPq).

\section{REFERENCES}

BANTIGNIES, B.; SEGUIN, J.; MUZAC, I.; DEDALDECHAMP, F.; GULICK, P. AND IBRAHIM, R. Direct evidence for ribonucleolytic activity of a PR-10-like protein from white lupin roots. Plant Molecular Biology, 42:871-881, 2000.

\section{BEWLEY, J. D. AND BLACK, M. Seeds: Physiology of Development and Germination. Plenum Press, New York, 1994. p. 293-310.}

BISWAS, T. K. Characterization of $\beta$ galactosidases from the germinating seeds of Vigna sinensis. Phytochemistry, 26: 359-364, 1987.

BRADFORD, M. M. A rapid and sensitive method for the quantitation of microgram quantities of protein utilizing the principle of dye-binding. Analytical Biochemistry, 72:248-254, 1976.
DETERMAN, H. Gel Chromatography, Springer Verlag, New York, 1969. p. 42-112.

DODDS, P. N.; CLARKE, A. E. AND NEWBIGIN, E. Molecular characterization of an S-like RNase of Nicotinina alata that is induced by phosphate starvation. Plant Molecular Biology, 31:227-238, 1996.

EL-SHOUNY, F. M. AND ALEXANDRESCU, J. Purification and some properties of the soluble ribonuclease in the sunflower roots. Revue Roumaine de Biochimie, 23:229233, 1986.

FARKAS, G. L. RNA-spliting enzymes. In: PARTHIER, B. AND BOUTER, D. (Eds.) Nucleic Acids and Proteins in Plants II. Structure, Biochemistry and Physiology of Nucleic Acid. Encyclopedia of Plant Physiology, vol. 14 B, Springer-Verlag, Berlin, 1982. p. 224-262.

FENNOY, S. L.; JAYACHANDRAN, S. AND BAILEY-SERRES, R. RNase activities are reduced concomitantly with conservation of total cellular RNA and ribossomes in $\mathrm{O}_{2-}$ deprived seedlings roots of maize. Plant Physiology, 115:1109-1117, 1997.

GOMES-FILHO, E. AND SODEK, L. Effect of salinity on ribonuclease activity of Vigna unguiculata cotyledons during germination. Journal of Plant Physiology, 132:307-311, 1988.

GOMES-FILHO, E. AND ENÉAS-FILHO, J. Atividade ribonucleásica de plântulas de Vigna unguiculata cv. Pitiúba durante a germinação e estádios iniciais de desenvolvimento. Revista Brasileira de Botânica, 14:45-50, 1991.

GOMES-FILHO, E.; PRISCO, J. T.; ENÉASFILHO, J.; TEIXEIRA, F. S. M. AND BEZERRA, J. R. M. V. Properties of a partially purified ribonuclease from cowpea cotyledons. Revista Brasileira de Fisiologia Vegetal, 6:27-36, 1994. 
GOMES-FILHO, E.; LIMA, C. R. F. M.; ENÉASFILHO, J.; GONDIM, L. A. AND PRISCO, J. T. Purification and properties of a ribonuclease from cowpea cotyledons. Biologia Plantarum, 42:525-532, 1999.

GREEN, P. J. The ribonucleases of higher plants. Annual Review of Plant Physiology and Molecular Biology, 45:421-445, 1994.

HANSON, D. M. AND FAIRLEY, J. L. Enzymes of nucleic acid metabolism from wheat seedlings. I. Purification and general properties of associated deoxyribonuclease, ribonuclease, and 3'-nucleotidase activities. Journal of Biological Chemistry, 244:2440-2449, 1969.

NAKAGAWA, A.; TANAKA, I.; SAKAI, R.; NAKASHIMA, T.; FUNATSU, G. AND KIMURA, M. Crystal structure of a ribonuclease from the seeds of bitter gourd (Momordica charantia) at 1.75 A resolution. Biochimica et Biophysica Acta, 1433:253260, 1999.

NELSON, D. L. AND COX, M. M. Lehninger Principles of Biochemistry. New York, Worth Publisers. 2000. p.243-292

PILEUR, F.; TOULME, J. J. AND CAZENAVE, C. Eukaryotic ribonucleases $\mathrm{HI}$ and HII generate characteristic hydrolytic patterns on DNA-RNA hybrids: further evidence that mitochondrial RNase $\mathrm{H}$ is an RNase HII. Nucleic Acids Research, 18:3674-3683, 2000.

PRISCO, J. T. AND VIEIRA, G. H. F. Effects of $\mathrm{NaCl}$ salinity on nitrogenous compounds and proteases during germination of Vigna sinensis seeds. Physiologia Plantarum, 36:317-320, 1976.

TANAKA, N.; ARAI, J.; INOKUCHI, N.; KOYAMA, T.; OHGI, K.; IRIE, M. AND
NAKAMURA, K. T. Crystal structure of a plant ribonuclease, RNase LE. Journal of Molecular Biology, 298:859-873, 2000.

TUVE, T. W. AND ANFINSEN, C. B. Preparation and properties of spinach ribonuclease. Journal of Biological Chemistry, 235:3437$3441,1960$.

TVORUS, E. K. Plant ribonucleases. Soviet Plant Physiology, 23:882-889, 1976.

WANG, H. AND NG, T. B. Isolation of a new ribonuclease from fresh fruiting bodies of the straw mushroom. Biochemical and Biophysical Research Communication, 264:714-718, 1999.

WILSON, C. M. Chromatographic separation of ribonucleases in corn. Biochimica et Biophysica Acta, 68:177-184, 1963.

WILSON, C. M. Plant nucleases I. Separation and purification of two ribonucleases and one nuclease from corn. Plant Physiology, 43:1332-1338, 1968.

WILSON, C. M. Plant nucleases. Annual Review of Plant Physiology, 26:187-208, 1975.

WILSON, C. M. Plant nucleases: Biochemistry and development of multiple molecular forms, in: RATTAZZI, M. C. (Ed), Isoenzymes: Current Topics in Biological and Medical Research, vol 5, Alan R. Liss, New York, 1982, p. 33-54.

YOKOYAMA, Z.-I.; MIYAMOTO, M. AND HIRANO, K. Purification and properties of acid ribonuclease in rice bran. Agricultural and Biological Chemistry, 46:247-253, 1982.

ZHAO, H.; LIU, K.F. AND WANG, D.W. A preliminary analysis on a group of low molecular weight RNases in wheat and related species, Acta Genetica Sinica, 27:423-427, 2000. 